\title{
Licking suppression and recovery as functions of contingency, locus, and frequency of punishment'
}

\author{
WILLIAM G. BRAUD and ROBERT E. PRYTULA, University \\ of Houston, Houston, Texas 77004
}

The suppression and recovery of a consummatory response (licking a sugar solution) was studied as a function of three parameters: (a) whether punishment was contingent upon the act or not, (b) locus of punishment application (tongue vs paws), and (c) frequency (zero to six trials). Shock temporarily suppressed responding in all groups, but only the Contingent Paw Shock group differed from the Control group in recovery time. Some conceptual considerations are suggested.

Especially since the provocative reviews of the punishment literature by Church (1963) and by Solomon (1964), there has been increased interest in the suppression and recovery of consummatory as opposed to instrumental behavior. Solomon has suggested that punishment may exercise pronounced suppressive effects on the former, as contrasted with the latter, type of behavior. It was the authors' purpose, in this experiment, to investigate the suppression of one particular consummatory act-licking of a nutritive solution-in some detail. Three parameters of punishment were studied: (a) whether punishment was contingent upon the performance of the act or not, (b) the locus of application of punishment (tongue vs paws), and (c) punishment frequency (varying from zero to six). The recovery of the suppressed response as a function of the same three punishment parameters was also noted.

\section{SUBJECTS}

The Ss were 32 male albino rats of the Cheek-Jones strain which were 80-90 days old at the beginning of training. The Ss were individually caged and were maintained at $80 \%$ of initial ad lib body weight throughout the experiment.

\section{APPARATUS}

Two experimental spaces were used in the experiment. The first consisted of a double, straight-alley runway apparatus which will be described in detail in a subsequent report. The second experimental space consisted of two unpainted wooden compartments, $6 \frac{1 / 4}{4} \times 3 \frac{1 / 2}{2} \times 13$ in. (inside dimensions). These compartments were covered by hinged, clear plastic tops; the floors consisted of 1/8-in. stainless steel grid bars spaced $1 / 4$-in. center to center. One end wall of each box was clear Plexiglas, the other wood. Goal cups (aluminum teaspoons) were located at the left walls of the respective compartments, $2 \mathrm{in}$. from the wooden end walls and $1 \frac{3 / 4}{4}$ in. above the floors. The goal cups and the grid floors could be independently electrified by a fused, variable voltage autotransformer through a $10 \mathrm{~K}$ fixed series resistor.

\section{PROCEDURE}

The Ss were trained, in the first apparatus, to run to the goal cups and lick their respective contents, which consisted of $0.25 \mathrm{cc}$ of an $8 \%$ (by weight) sucrose-distilled water solution. The Ss were given five trials per day for six days; they were run in squads of four animals, with an intertrial interval of approximately $5 \mathrm{~min}$. The Ss were given their daily ration of Wayne Lab Chow (varied so as to maintain Ss at appropriate body weights) $1 \mathrm{~h}$ after their last daily trial; water was continually available. The purpose of this runway training was to establish a strong, short-latency approach to the goal cup.

On Day 7 , the 32 Ss were divided randomly into four groups of eight Ss each. These four groups were treated differentially in the second (punishment) apparatus, and were designated according to the contingency and locus of shock punishment. The Contingent Tongue Shock group was punished for licking the goal cup by attaching one side of the shock output to the teaspoon and the other side to the grid floor; the Ss of this group were shocked at the tongue whenever a goal cup contact was made. The Contingent Paw Shock group was also punished for licking the goal cup, but for Ss of this group shock was applied only to the paws by electrifying the grid alone. Paw-shock duration was equal to time in contact with the goal cup (drinkometer controlled). Each $S$ of the Yoked Paw Shock group was run in a second punishment compartment which was physically yoked to the compartment of an $\mathrm{S}$ of the Contingent Paw Shock group: whenever the contingent $S$ contacted the goal cup, both itself and its yoked pair-member were shocked. Shock voltage in all cases was $75 \mathrm{~V}$ ac through a $10 \mathrm{~K}$ resistor. According to this yoked compartment arrangement, the Ss of the Yoked group received exactly the same durations and temporal distributions of shocks as the Ss of the Contingent group, but shock for the former Ss was independent of their behavior. The Ss of the Control group were never shocked in the apparatus.

On Days 7, 8, and 9, all Ss were given two daily trials in the second apparatus. A trial consisted of placing $S$ into the grid-floored compartment and recording its latency to lick the $0.25 \mathrm{cc}$ solution of sucrose placed in the goal cup. A shocked S was removed from the apparatus immediately after receiving its shock. If $S$ did not lick by $5 \mathrm{~min}$, it was removed from the compartment and a latency of $5 \mathrm{~min}$ was recorded. The Ss of the Control group entered the compartment, licked, and were removed, but were never shocked. The Ss were run in squads with an intertrial interval of approximately $30 \mathrm{~min}$.

All Ss remained undisturbed on Day 10 , but beginning on Day 11 , a series of recovery tests were administered in the second apparatus. All Ss were placed in the compartment and time to contact the goal cup was recorded; no shocks were administered. The Ss were tested at the rate of two trials per day until they responded with a latency equal to or less than that of their Preshock trial (first trial of Day 7), at which point they were no longer tested.

\section{RESULTS}

By the end of the sixth day of runway training, all Ss were approaching the goal cups in the alley goal boxes at asymptotic running speeds of approximately $5 \mathrm{ft} / \mathrm{sec}$. The four randomly formed groups did not differ reliably $(p>.05)$ in either this running speed measure or in latency to lick the goal cup on the first (Preshock) trial in the punishment compartment.

Mean times to lick on Pretest, Suppression, and Recovery trials for the four groups are presented in Fig. 1. During the six suppression trials, the three shocked groups each received a mean of 2.75 shocks. This small number of shocks was sufficient to suppress licking completely (latency of $5 \mathrm{~min}$ ) in $6 / 8$ of the Ss in the Contingent Tongue Shock group, and in $7 / 8$ of the Ss in the Contingent Paw Shock group, but in only $2 / 8$ of the Ss in the Yoked Paw Shock group. There was no decrement in consummatory behavior in the Control group; latencies remained at approximately $1.0 \mathrm{sec}$ from Trial 3 until the conclusion of the experiment. Analysis of variance indicated that the four groups differed significantly on the last day of suppression training $(F=47.49, \mathrm{df}=3 / 28, \mathrm{p}<.01)$; a critical difference test indicated that each group differed reliably $(p<.01)$ from every other group, except the Contingent Paw Shock and Contingent Tongue Shock groups, which did not differ $(\mathrm{p}>.01)$.

Recovery of licking was complete (latency $\leqslant$ Pretest 


\section{REFERENCES}

BRONSON, F. H., \& ELEFTHERIOU, B. E. Adrenal responses to crowding in Peromyscus and C57B $1 / 10 \mathrm{~J}$ mice. Physiological Zoology, $1963,36,161-166$.

BRONSON, F. H., \& ELEFTHERIOU, B. E. Adrenal response to fighting in mice: Separation of physical and psychological causes. Science, $1965 a, 147,627-628$.

BRONSON, F. H., \& ELEFTHERIOU, B. E. Behavioral, pituitary and adrenal correlates of controlled fighting in mice. Physiological Zoology, 1965b, 38, 406-411.

LEVINE, S., ALPERT, M., \& LEWIS, G. W. Differential maturation of an adrenal response to cold stress in rats manipulated in infancy. Journal of Comparative \& Physiological Psychology, 1958, 51, 774-777.

LOUCH, C. D., \& HIGGINBOTHAM, M. The relation between social rank and plasma corticosterone levels in mice. General \& Comparative Endocrinology, 1967, 8, 441-444.

MASON, J. W., \& BRADY, J. V. The sensitivity of psycho-endocrine systems to social and physical environment. In P. H. Liederman \& D. Schapiro (Eds.), Psychobiological approaches to social behaviour. London: Tavistock, 1965. Pp. 4-23.
SELYE, H. The physiology and pathology of exposure to stress. Montreal: Acta, 1950.

THIESSEN, D. D. Population density and behavior: A review of theoretical and physiological contributions. Texas Reports on Biology and Medicine, 1964, 22, 266-314.

THIESSEN, D. D., ZOLMAN, J. F., \& RODGERS, D. A. Relation between adrenal weight, brain cholinesterase activity and hole-in-thewall behavior of mice under different living conditions. Journal of Comparative \& Physiological Psychology, 1962, 55, 186-190.

WELCH, B. L. Psychophysiological response to the mean level of environmental stimulation: A theory of environmental integration. Medical aspects of stress in the military climate. Walter Reed Army Institute, 1964. Pp. 39-99.

NOTES

1. Supported by Science Research Council studentship, and by grant from the Wellcome trust. I thank Dr. J. H. Crook for critical comments and discussion.

2. Present address: University of Nottingham.

\section{(Continued from page 16)}

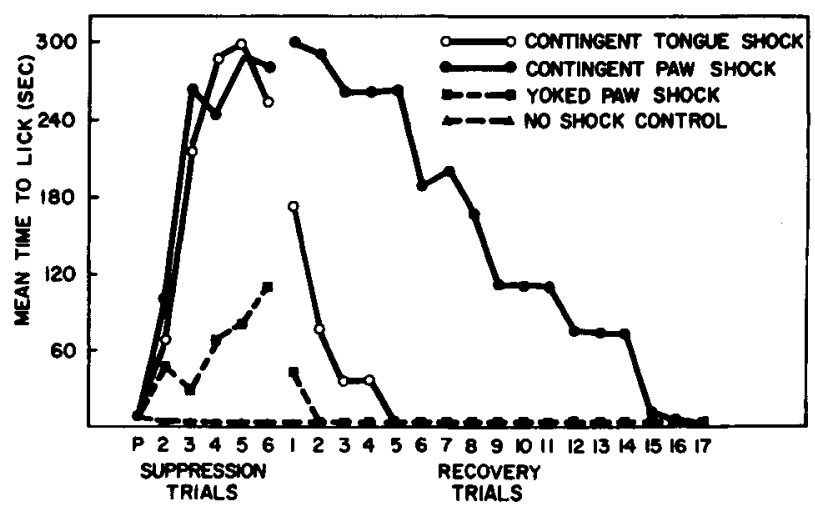

Fig. 1. Mean times to lick during Pretest, Suppression, and Recovery trials in the punishment apparatus.

latency) in all Ss of the Yoked Paw Shock and Contingent Tongue Shock groups after only two and five recovery trials, respectively. The Ss in the Contingent Paw Shock group, however, required 17 trials for complete recovery. Analysis of variance indicated that the four groups differed significantly in number of trials to the recovery criterion $(F=16.42$, $\mathrm{df}=3 / 28, \mathrm{p}<.01)$; the Contingent Paw Shock group differed reliably $(\mathrm{p}<.01)$ from the other three groups, which latter did not differ among themselves.

\section{DISCUSSION}

The results indicate that contingent shocks of either the paws or the tongue effectively suppress approach and licking behavior in the white rat, while an equal number of noncontingent shocks does not. This agrees rather closely with a similar finding by Myer (1968), who used paw shock to suppress attack behavior (mouse-killing in rats). Both suppression and recovery occurred more rapidly in the present experiment than was the case in Myer's study.

Although locus of application of punishment had no effect during the suppression phase, it profoundly influenced the course of recovery. Such a finding, besides having obvious methodological implications for the measurement of decremental effects, is both interesting and puzzling. Punishment of such consummatory acts as eating (Masserman \& Pechtel, 1953), attack (Adler \& Hogan, 1963; Myer, 1966), and sexual behavior (Beach et al, 1956) has produced immediate and long-lasting suppression. In the present experiment, when the actual consummatory act of licking was punished, it recovered almost immediately. Whether such an effect is attributable to an instrumental/consummatory distinction is unclear. Tongue pain may be more "ethologically novel" than paw pain, and consequently may be less effective in deterring behavior. Or perhaps approach-licking, in the present situation, has more of an approach than a licking component.

Care should be taken in attributing any differential effects of, say, tongue and paw shock to their "consummatory" and "nonconsummatory" nature. Those responses usually termed "consummatory" may be distinguished from "instrumental" responses in at least three ways: (a) their consummatory or instrumental nature per se, (b) the anatomical/functional nature of the particular effectors involved, and (c) their frequency of usage (overtraining, etc.). One way of dissociating these three factors would be to note the effects of punishment on the same response when it is functioning instrumentally or consummatorily (with experience equated). While such an experiment might be beset by both practical and logical difficulties (e.g., is lever-pressing for brain stimulation or stomach- or mouth-loading instrumental or consummatory?), it might yield quite illuminating findings.

\section{REFERENCES ${ }^{2}$}

MYER, J. S. Associative and temporal determinants of facilitation and inhibition of attack by pain. Journal of Comparative \& Physiological Psychology, 1968, 66, 17-21.

SOLOMON, R. L. Punishment. American Psychologist, 1964, 19, 239-253.

\section{NOTES}

1. This study was supported by a University of Houston Faculty Research Support Program grant to the senior author.

2. All other references may be found in the two cited references. 